\title{
Response of chloroplasts of tolerant and sensitive wheat genotypes to manganese excess: structural and biochemical properties
}

\author{
Apolonia Sieprawska $^{1} \cdot$ Maria Filek $^{1} \cdot$ Anna Tobiasz $^{2} \cdot$ Elżbieta Bednarska-Kozakiewicz $^{3} \cdot$ \\ Stanisław Walas ${ }^{2} \cdot$ Danuta Dudek-Adamska $^{2} \cdot$ Emilia Grygo-Szymanko $^{2}$
}

Received: 16 June 2016/Revised: 11 July 2016/Accepted: 12 November 2016/Published online: 22 November 2016

(C) The Author(s) 2016. This article is published with open access at Springerlink.com

\begin{abstract}
Effects related to the adaptation of wheat to $\mathrm{Mn}$ excess were determined by structural and biochemical characterization of chloroplasts obtained from three-leaf seedlings of Mn-treated wheat. Chloroplasts were isolated from two wheat genotypes: sensitive (Raweta) and tolerant (Parabola) cultivated in hydroponic conditions in Hoagland nutrient supplemented with 0 (control), 5, 10, and $20 \mathrm{mmol} \mathrm{dm}^{-3} \mathrm{MnSO}_{4}$. Microscopic observations of the chloroplast structure revealed differences in the size and starch presence between both objects. Changes indicating the stresogenic influence of $\mathrm{Mn}$ on Raweta seedlings appeared already at the $\mathrm{Mn}$ dose of $10 \mathrm{mmol} \mathrm{dm}^{-3}$, whereas on Parabola, only at $20 \mathrm{mmol} \mathrm{dm}^{-3}$. Biochemical analysis indicated the differences in starch content. Results of measurements of lipid peroxidation, polarity, and electrokinetic potential of chloroplasts point to Mn-stimulated modifications of chloroplast membranes which occurred to be larger for Raweta. The activation of antioxidative enzymes (SOD and POX) shows that ROS are generated under Mn-excess conditions. The content of $\mathrm{Mn}$ and $\mathrm{Cu}$, $\mathrm{Fe}, \mathrm{Mo}$, and $\mathrm{Zn}$ (microelements) as well as $\mathrm{Ca}, \mathrm{Mg}, \mathrm{K}, \mathrm{P}$, and $\mathrm{S}$ (macroelements) in chloroplasts was determined by mass (ICP MS) and plasma optic emission (ICP OES)
\end{abstract}

Communicated by Z. Miszalski.

Apolonia Sieprawska

apolonia.sieprawska@gmail.com

1 Department of Biochemistry, Biophysics and Biotechnology, Institute of Biology, Pedagogical University, Podchorążych 2, 30-084 Krakow, Poland

2 Department of Analytical Chemistry, Faculty of Chemistry, Jagiellonian University, Ingardena 3, 30-060 Krakow, Poland

3 Faculty of Biology and Environmental Protection, Nicolaus Copernicus University, Lwowska 1, 87-100 Toruń, Poland spectrometry. Raweta accumulated greater amount of Mn in comparison with Parabola at all Mn doses in media. Increased concentration of $\mathrm{Mn}$ was accompanied with a decrease of uptake other investigated elements (except for $\mathrm{K})$.

Keywords Chloroplasts · Manganese · Microand macroelements . Wheat tolerance

\section{Introduction}

$\mathrm{Mn}$ is an element necessary for plants as microelement, however, in excess can potentially be toxic. Mn presence is indispensable as a component of the oxygen-evolving complex in photosystem II (PSII). It catalyzes the watersplitting reaction which produces oxygen and provides electrons for the photosynthetic electron transport chain (Goussias et al. 2002; Nickelsen and Rengstl 2013). Moreover, $\mathrm{Mn}$ is required for carbohydrate and lipid biosynthesis in plants and acts as a direct cofactor of a variety of enzymes, among others in Mn superoxide dismutase (MnSOD), a principal antioxidant enzyme in cellular redox reactions (Marschner 2012). On the other hand, $\mathrm{Mn}$ at toxic level may itself induce the oxidative stress by generation of reactive oxygen species. It was also found that accumulation of $\mathrm{Mn}$ in high concentration can prevent the uptake and translocation of other essential elements, such as $\mathrm{Ca}, \mathrm{Mg}, \mathrm{Fe}$, and $\mathrm{P}$, due to the similarity in ionic radii (Marschner 2012; Millaleo et al. 2013). The disturbance of nutritional balance, resulting in a lack of crucial elements, increases the toxic effect of an excess metal uptake (Sharma et al. 2004; Bouazizi et al. 2010). Mn absorbed from soil was found in many locations in plant cells, including chloroplasts, cell wall, mitochondria, and 
Golgi apparatus (Pittman 2005). It was demonstrated the species-dependence for Mn compartmentation and distribution in leaves which correlated with the abilities of plants to maintain redox and ion homeostasis in stress conditions (Ke et al. 2007; Qiu et al. 2008). Thus, the selection of genotypes which takes into account their stress-tolerance is important for plant breeding. In our previous study, performed in in vitro cultures of wheat cells, we found that $\mathrm{Mn}$ at toxic level differentiated tolerant and sensitive genotypes chosen on the basis of their susceptibility to osmotic stress (Sieprawska et al. 2016). The aim of this work was to find whether and to what extent: (1) Mn may be accumulated in chloroplasts of these tolerant and sensitive wheat genotypes and (2) may stimulate the changes in structural and physiological properties of these organelles. Despite the significance of chloroplasts in photosynthesis and in consequence for proper growth and development of plants, relatively little is known about $\mathrm{Mn}$ localization in organelles of crop cells (Lidon et al. 2004). The understanding of the molecular mechanisms of this metal action in plants is important for the choice of appropriate concentrations of Mn during fertilization and for selection of the varieties of increased tolerance to Mn excess.

Seeds of tolerant (cv. Parabola) and sensitive (cv. Raweta) spring wheat (Triticum aestivum), selected on the basis of data presented by Grzesiak et al. (2013), were cultivated under hydroponics in the solution of Hoagland nutrient $(1: 1 ; \mathrm{v}: 1)$ additionally supplemented with 0 (control), 5, 10, and $20 \mathrm{mmol} \mathrm{dm}^{-3} \mathrm{MnSO}_{4}$ for about 2 weeks (three-leaf seedlings). During the whole experiment, the photoperiod was set at $16 \mathrm{~h}\left(17 / 20{ }^{\circ} \mathrm{C}\right.$ night/day $)$, the relative humidity at $45-50 \%$, and light intensity at $1000 \mu \mathrm{mol}$ (photon) $\mathrm{m}^{-2} \mathrm{~s}^{-1}$ (SQS, Hansatech Ltd, Kings Lynn, UK). Microscopic observations were carried out using stereoscopic microscope (Nikon SMZ 1500) after fixation of the second leaf in $4 \%$ paraformaldehyde and cutting on vibrating blade microtome (Leica VT 1200S) (Filek et al. 2010; Łabanowska et al. 2012). Chloroplasts were isolated from fresh leaf tissues by the method of Block et al. (1983). The isolation buffer contained $50 \mathrm{mM}$ Tris $-\mathrm{HCl}, 5 \mathrm{mM}$

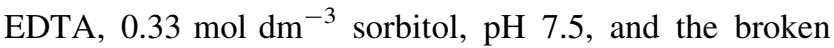
chloroplasts was separated by centrifugation in $40 / 80 \%$ Percoll gradient. The measurements of membrane polarization and of electrokinetic potential were performed within a time period not longer than $0.5 \mathrm{~h}$ after preparation. Membrane polarization was detected spectrofluorometrically (Perkin-Elmer, LS50B) using 1,6-diphenyl-1,3,5hexatrienen fluorophore, as it was described in Filek et al. (2009). Electrokinetic potential was measured Zeta-PLUS apparatus (Brookhaven, USA) (Filek et al. 2009). Microelements were determined by inductively coupled plasma mass spectrometry (ICP MS) using Elan DRC-e (Perkin-Elmer) apparatus and macroelements by an inductively coupled plasma optic emission spectrometer ICP OES Optima 2100 (Perkin-Elmer) according to (Sieprawska et al. 2014). Superoxide dismutase (SOD, EC 1.15.11) activity was registered at $\lambda=595 \mathrm{~nm}$ (BiochromUltrospec II, LKB, Sweden), and activities of peroxidases (POD, EC 1.11.1.7) were measured at $\lambda=485 \mathrm{~nm}$ (Grzesiak et al. 2013). Malon dialdehyde (MDA) content, as an indicator of lipid peroxidation, was determined via changes in thiobarbituric acid (TBA) concentration, according to Tobiasz et al. (2014). The content of starch was determined spectrometrically (RayLeigh 1601) at $\lambda=625 \mathrm{~nm}$ with antrone reagent, as described earlier in detail by Janeczko et al. (2010). Data from various Mn treatments were analyzed statistically using the SAS ANOVA software. Comparisons of the means were done using Duncan's Multiple Range test with PC SAS 8.0.

The microscopic photos allowed to observe typical, well-developed chloroplasts with single, small starch granules in parenchymatic cells of both genotypes cultured in control conditions (Fig. 1Ia, IIa). Growth of plants in the presence of $5 \mathrm{mmol} \mathrm{dm}{ }^{-3}$ of $\mathrm{Mn}$ caused changes in the chloroplast properties characterized in an accumulation of large and numerous starch grains in tolerant (Fig. 1Ib) as well as in sensitive (Fig. 1IIb) wheat. It is worth to notice that the microscopic observations of ultrastructural changes in plants treated with manganese were performed primarily for dicots (Santandrea et al. 1998). Biochemical analysis of starch content confirmed its increase, in comparison with control, with greater effects in Raweta plants (Table 1). At $10 \mathrm{mmol} \mathrm{dm}^{-3}$ of Mn, significant differences between the chloroplasts structure of both genotypes were detected: in Raweta-a marked reduction in size of plastids, in which very small, single starch granules were localized (Fig. 1IIc), whereas in Parabola-only slight reduction in chloroplasts size as well as in starch content were found (Fig. 1Ic). These observations agree with the results of biochemical analysis of starch content (Table 1) and indicate that $\mathrm{Mn}$ at this level is toxic for sensitive genotypes and probably disturbs photosynthesis leading to a significant decrease of starch production. Mn-mediated inhibition of photosynthesis and energy distribution within photosystems was observed by Lidon et al. (2004) in rice chloroplasts. Photosynthesis disruption is responsible for generation of excess of ROS. An increase in ROS production at $\mathrm{Mn}$ presence in environment was indirectly demonstrated by an increase in activity of SOD and POX. Superoxide dismutases (SOD) are key enzymes catalyzing the dismutation of $\mathrm{O}_{2}$ to $\mathrm{H}_{2} \mathrm{O}_{2}$, while peroxidases (POD) decompose of $\mathrm{H}_{2} \mathrm{O}_{2}$ to water (Choudhary et al. 2007; Tanyolac et al. 2007). Greater changes in activity of these enzymes, noted for Raweta chloroplasts, confirms formation of larger amounts of ROS in this genotype in comparison to Parabola. However, in response to $\mathrm{Mn}$ at 

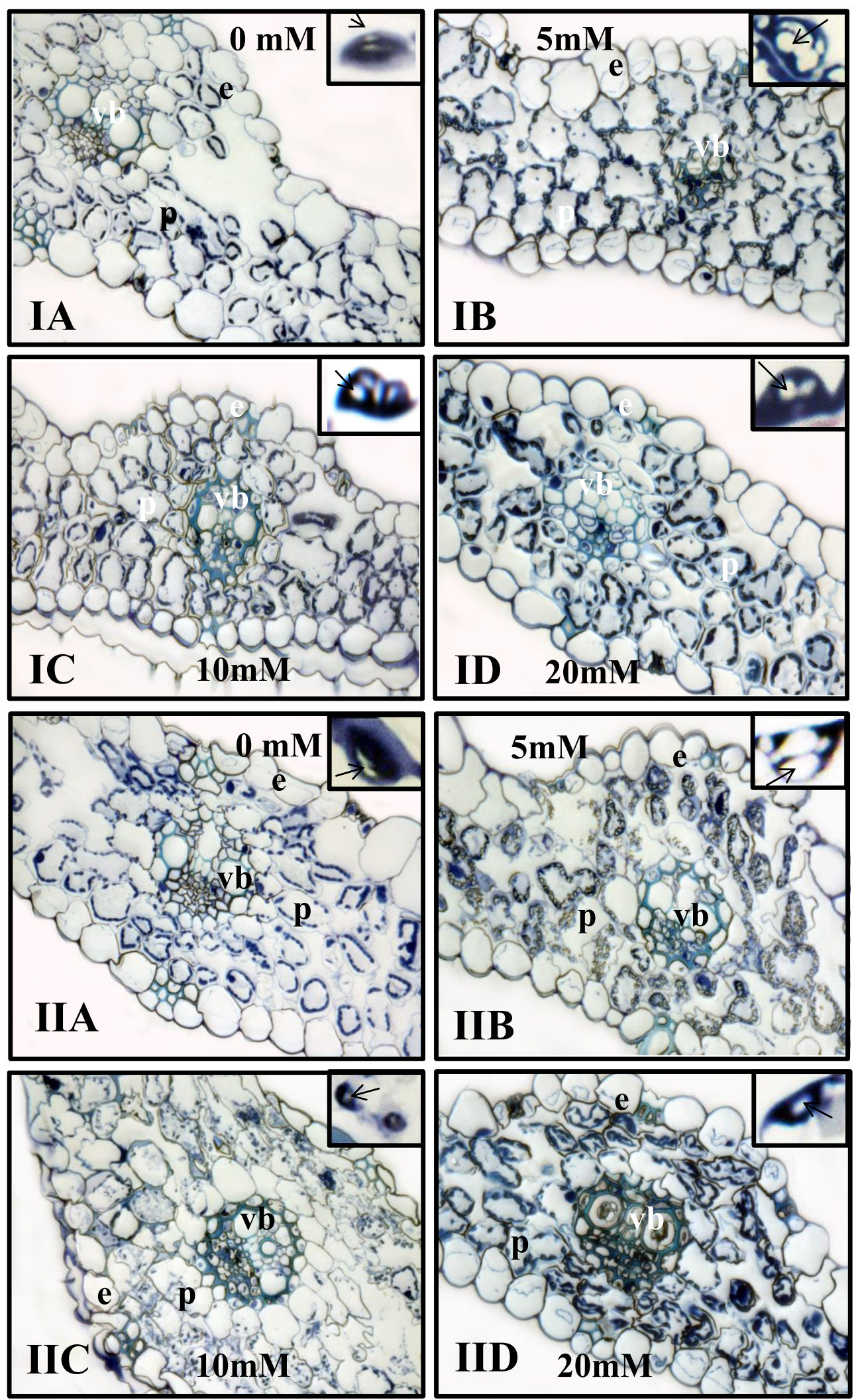

Fig. 1 Sections of leaves of Parabola $(I)$ and Raweta (II). Plants were cultured at hydroponic conditions with Hoagland nutrient $(0, a)$, with nutrient supplemented with $5 \mathrm{mmol} \mathrm{dm}^{-3} \mathrm{MnSO}_{4} \quad(b)$, $10 \mathrm{mmol} \mathrm{dm}^{-3} \mathrm{MnSO}_{4}(c)$ and $20 \mathrm{mmol} \mathrm{dm}{ }^{-3} \mathrm{MnSO}_{4}(d)$. Inset

magnified fragment with starch granules, marked by arrow). $e$ epidermis, $p$ parenchymatic cell, $v$ vascular bound. For $a-$ $d$ magnification was $40 \times$; for inset $100 \times$ 
Table 1 Content of malon dialdehyde (MDA) in $\mathrm{mM} / \mathrm{g}$ of the fresh weight $(\mathrm{FW})$, and polarization of membranes, electrokinetic potential in $\mathrm{mV}$, starch content (mg/g FW), superoxide dismutases (SOD), and peroxidases (POX) activities (U/mg protein) in chloroplasts obtained from the seedlings of tolerant (Parabola) and sensitive (Raweta) wheat

\begin{tabular}{|c|c|c|c|c|c|c|c|}
\hline Object & $\begin{array}{l}\text { Mn treatment } \\
(\mathrm{mM})\end{array}$ & $\begin{array}{l}\text { MDA }(\mathrm{mM} / \mathrm{g} \\
\text { FW) }\end{array}$ & Polarization & $\begin{array}{l}\text { Elctrokinetic potential } \\
(\mathrm{mV})\end{array}$ & $\begin{array}{l}\text { Starch }(\mathrm{mg} / \mathrm{g} \\
\text { FW) }\end{array}$ & $\begin{array}{l}\text { SOD (U/mg } \\
\text { protein) }\end{array}$ & $\begin{array}{l}\mathrm{POX}(\mathrm{U} / \mathrm{mg} \\
\text { protein) }\end{array}$ \\
\hline \multicolumn{8}{|c|}{ Parabola } \\
\hline & 0 & $0.011 \pm 0.001^{\mathrm{c}}$ & $0.23 \pm 0.01^{\mathrm{d}}$ & $-26.8 \pm 0.03^{\mathrm{d}}$ & $2.31 \pm 0.09^{b}$ & $0.49 \pm 0.03^{c}$ & $0.36 \pm 0.02^{\mathrm{c}}$ \\
\hline & 5 & $0.015 \pm 0.001^{\mathrm{b}}$ & $0.42 \pm 0.02^{\mathrm{c}}$ & $-23.3 \pm 0.02^{\mathrm{c}}$ & $3.29 \pm 0.11^{\mathrm{a}}$ & $0.51 \pm 0.04^{\mathrm{c}}$ & $0.39 \pm 0.03^{\mathrm{c}}$ \\
\hline & 10 & $0.015 \pm 0.001^{\mathrm{b}}$ & $0.50 \pm 0.02^{\mathrm{b}}$ & $-22.8 \pm 0.02^{\mathrm{b}}$ & $1.82 \pm 0.05^{\mathrm{c}}$ & $0.82 \pm 0.06^{\mathrm{b}}$ & $0.49 \pm 0.04^{\mathrm{b}}$ \\
\hline & 20 & $0.019 \pm 0.002^{\mathrm{a}}$ & $0.58 \pm 0.03^{\mathrm{a}}$ & $-19.2 \pm 0.02^{\mathrm{a}}$ & $1.79 \pm 0.04^{\mathrm{c}}$ & $1.12 \pm 0.05^{\mathrm{a}}$ & $0.63 \pm 0.04^{\mathrm{a}}$ \\
\hline \multicolumn{8}{|c|}{ Raweta } \\
\hline & 0 & $0.019 \pm 0.002^{\mathrm{c}}$ & $0.21 \pm 0.01^{\mathrm{d}}$ & $-26.5 \pm 0.03^{\mathrm{c}}$ & $2.67 \pm 0.09^{b}$ & $0.47 \pm 0.04^{\mathrm{c}}$ & $0.41 \pm 0.03^{\mathrm{d}}$ \\
\hline & 5 & $0.049 \pm 0.003^{\mathrm{b}}$ & $0.28 \pm 0.02^{\mathrm{c}}$ & $-24.2 \pm 0.02^{\mathrm{b}}$ & $4.02 \pm 0.08^{\mathrm{a}}$ & $0.77 \pm 0.05^{\mathrm{b}}$ & $0.63 \pm 0.04^{\mathrm{c}}$ \\
\hline & 10 & $0.055 \pm 0.004^{\mathrm{b}}$ & $0.42 \pm 0.03^{\mathrm{b}}$ & $-22.3 \pm 0.02^{\mathrm{a}}$ & $1.70 \pm 0.03^{\mathrm{c}}$ & $1.26 \pm 0.02^{\mathrm{a}}$ & $1.10 \pm 0.03^{\mathrm{a}}$ \\
\hline & 20 & $0.060 \pm 0.005^{\mathrm{a}}$ & $0.51 \pm 0.04^{\mathrm{a}}$ & $-22.4 \pm 0.02^{\mathrm{a}}$ & $1.66 \pm 0.03^{\mathrm{c}}$ & $1.30 \pm 0.02^{\mathrm{a}}$ & $1.03 \pm 0.03^{\mathrm{b}}$ \\
\hline
\end{tabular}

Plants were cultured in Hoagland nutrient (0) and nutrients supplemented with $\mathrm{MnSO}_{4}$ (at 5, 10, and $20 \mathrm{mmol} \mathrm{dm}^{-3}$ )

Values are means $(n=3) \pm$ SE. Various letters indicate significant $(P<0.05)$ differences between treatments

concentration of $20 \mathrm{mmol} \mathrm{dm}^{-3}$, no spectacular differences between genotypes in chloroplast structure were found. In both, chloroplasts contained single starch granules (Fig. 1Id, IId). However, comparing the changes in activity of enzymes, the further increase of enzymes" activities in tolerant genotype may suggest continued stimulation of antioxidant defense system (Table 1). In sensitive genotype, insignificant changes of the antioxidants activation (and even a decrease, in the case of POX) found for $20 \mathrm{mmol} \mathrm{dm}^{-3} \mathrm{Mn}$ dose, as compared to $10 \mathrm{mmol} \mathrm{dm}^{-3}$, indicate that $20 \mathrm{mmol} \mathrm{dm}^{-3} \mathrm{Mn}$ is the highest concentration of this metal above which the damage in the structure of Raweta chloroplasts (induced by ROS excess) may occur. ROS produced in excess quantities may react with the chloroplasts membranes. It was shown that in Raweta cells, lipid peroxidation (expressed by MDA content) in chloroplasts membranes was greater (even at $5 \mathrm{mmol} \mathrm{dm}{ }^{-3} \mathrm{Mn}$ ) than in Parabola (Table 1). The increase of lipid peroxidation serves as an indicator of ROS generation and, therefore, of the intensity of the stress action (Sharma et al. 2012). Larger changes of lipid per-

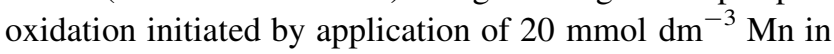
sensitive genotype were confirmed by data of membrane polarization indicating a decrease of unsaturation of lipid fatty acids. The increased values of electrokinetic potential inform about changes in polar part of membranes in the direction of less charged lipids (Gzyl-Malcher et al. 2010, 2011). Smaller changes of these parameters, registered for Parabola, indicate less impact of $\mathrm{Mn}$ on its membranes which may result from lower generation of ROS in tolerant genotypes. Toxicity of Mn, higher for Raweta chloroplasts, arises probably from greater accumulation of this metal in comparison to Parabola (Table 2).
At control conditions, Hoagland nutrients contained $10 \mu \mathrm{mol} \mathrm{dm}{ }^{-3}$ of $\mathrm{Mn}$ ions (equivalent of $1.7 \mathrm{mg} \mathrm{dm}^{-3}$ of this element in diluted Hoagland nutrient). This concentration, at which Mn level in chloroplasts was about 3.7 and $4.2 \mu \mathrm{g} / \mathrm{g}$ DW for Parabola and Raweta, respectively, did not induce stressogenic effects (as evidenced by similarity in microscopic images and biochemical parameters of both genotypes). However, higher uptake of Mn by Raweta chloroplasts when plants were cultivated at all growth media (control and with additional Mn supplementation) indicates that this sensitive genotype can be a better accumulator of this element. Interestingly, absorption of other elements (except of $\mathrm{Mg}$ ) in Raweta chloroplasts was lower at control conditions in comparison with that observed for tolerant Parabola. Mn at concentrations of 5 and $10 \mathrm{mmol} \mathrm{dm}^{-3}$ caused of about 5.0- and 6.2-fold increase of Mn uptake (in comparison with control) for Parabola and Raweta, respectively, independently on used $\mathrm{Mn}$ doses. The highest $\mathrm{Mn}$ application $\left(20 \mathrm{mmol} \mathrm{dm}^{-3}\right)$ led to about 7.5- and 8.3-fold enhancement of absorption of this element. Comparison of these data with results of biochemical analysis and microscopic observations point to that about sixfold higher (than in control) accumulation of $\mathrm{Mn}$ in sensitive genotype seems to induce the stressogenic effects, whereas in tolerant one, such effects appear after about 7.5-fold rise of Mn uptake. The presence of $\mathrm{Mn}$ in chloroplasts, even at the smallest studied Mn application $\left(5 \mathrm{mmol} \mathrm{dm}{ }^{-3}\right)$, causes a reduction of absorption of all analyzed essential elements (except for K, which concentration was at the same level at every Mn dose) (Table 2). The biggest changes were observed for $\mathrm{Mg}, \mathrm{Fe}$, and $\mathrm{P}$ and were in agreement with data of Marschner (2012) and Millaleo et al. (2013) described that Mn effect on blocking 


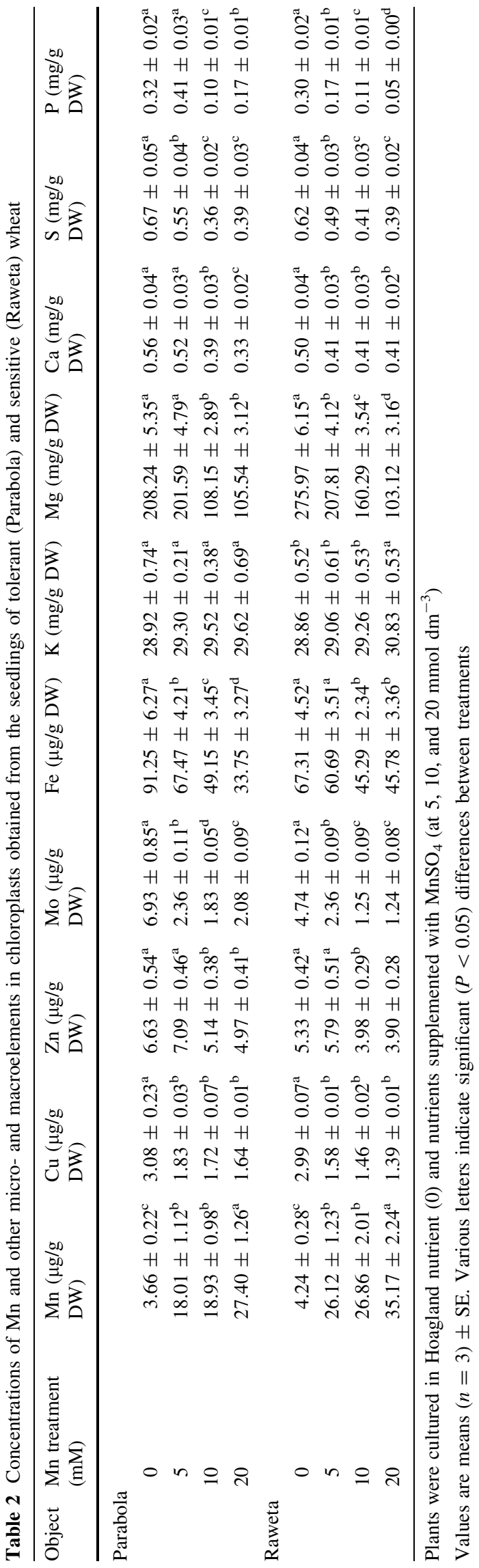

the transport and translocation of other elements can be related similarity of ionic radii. The finding that the excess of $\mathrm{Mn}$ accumulation inhibits the uptake of all elements, important for proper course of physiological processes, may additionally increase stressogenic effects of $\mathrm{Mn}$.

It can be concluded that $\mathrm{Mn}$ may be transferred into chloroplasts of wheat genotypes but its uptake is not proportional to Mn application. Sensitive genotype seems to be a better $\mathrm{Mn}$ accumulator in comparison with tolerant one, in spite of the weaker absorption of other elements (except of $\mathrm{Mg}$ ). It could be that this disproportion between $\mathrm{Mn}$ and elements essential for proper metabolism is responsible for higher sensitivity of Raweta plants to $\mathrm{Mn}$ stress. Disruption of photosynthesis entails the increase of ROS generation, especially in sensitive genotype, what additionally can enhance the stress effects. Mn concentration of $20 \mathrm{mmol} \mathrm{dm}^{-3}$ in growth media seems to be extreme for both sensitive and tolerant wheat genotypes because of destruction of chloroplast structure.

Author contribution statement Study conception and design: Sieprawska A., Filek M., Tobiasz A. Acquisition of data: Tobiasz A., Bednarska-Kozakiewicz E., Sieprawska A., Walas S., Dudek-Adamska D, Grygo-Szymanko E. Analysis and interpretation of data: Filek M., Sieprawska A., Tobiasz A., Bednarska-Kozakiewicz E. Drafting of manuscript: Sieprawska A., Filek M. Critical revision: Sieprawska A, Filek M, Tobiasz A, Walas S, Bednarska-Kozakiewicz E., Walas S., Dudek-Adamska D., Grygo-Szymanko E.

Acknowledgements This work was supported by a Grant from the National Science Center, Poland, Project No. 2013/11/D/ST4/02839.

Open Access This article is distributed under the terms of the Creative Commons Attribution 4.0 International License (http://crea tivecommons.org/licenses/by/4.0/), which permits unrestricted use, distribution, and reproduction in any medium, provided you give appropriate credit to the original author(s) and the source, provide a link to the Creative Commons license, and indicate if changes were made.

\section{References}

Block MA, Dorne A-J, Joyard J, Douce R (1983) The acyl-CoA synthetase and acyl-CoA thioesterase are located on the outer and inner membrane of the chloroplast envelope, respectively. FEBS Lett 153:377-381

Bouazizi H, Jouili H, Geitmann A, El Ferjani E (2010) Copper toxicity in expanding leaves of Phaseolus vulgaris L.: antioxidant enzyme response and nutrient element uptake. Ecotox Environ Safe 73:1304-1308

Choudhary M, Jetley UK, Abash Khan M, Zutshi S, Fatma T (2007) Effect of heavy metal stress on proline, malondialdehyde, and superoxide dismutase activity in the cyanobacterium Spirulina platensis-S5. Ecotox Environ Safe 66:204-209

Filek M, Zembala M, Hartikainen H, Miszalski Z, Kornaś A, Wietecka-Posłuszny R (2009) Changes in wheat plastid 
membrane properties induced by cadmium and selenium in presence/absence of 2,4-dichlorophenoxyacetic acid. Plant Cell Tiss Organ Cult 96:19-28

Filek M, Kościelniak J, Łabanowska M, Bednarska E, Bidzińska E (2010) Selenium-induced protection of photosynthesis activity in rape (Brassica napus) seedlings subjected to cadmium stress. Fluorescence and EPR measurements. Photosynth Res 105:27-37

Goussias C, Boussac A, Rutherford AW (2002) Photosystem II and photosynthetic oxidation of water: an overview. Philos Trans R Soc Lond Biol Sci 357:1369-1381

Grzesiak M, Filek M, Barbasz A, Kreczmer B, Hartikainen H (2013) Relationships between polyamines, ethylene, osmoprotectants and antioxidant enzymes activities in wheat seedlings after short term PEG- and NaCl-induced stresses. Plant Growth Regul 69:177-189

Gzyl-Malcher B, Zembala M, Filek M (2010) Effect of tocopherol on surface properties of plastid lipids originating of wheat cultivated in cadmium presence. Chem Phys Lipids 163:74-81

Gzyl-Malcher B, Filek M, Brezesiński G (2011) Mixed DPPC/ DPTAP monolayers at the air/water interface: influence of indolilo-3-acetic acid and selenite ions on the monolayer morphology. Langmuir 27:10886-10893

Janeczko A, Biesaga-Kościelniak J, Oklešt'ková J, Filek M, Dziurka M, Szarek-Łukaszewska G, Kościelniak J (2010) Role of 24-epibrassinolide in wheat production: physiological effects and uptake. J Agron Crop Sci 196:311-321

Ke W, Xiong ZT, Chen S, Chen J (2007) Effects of copper and mineral nutrition on growth, copper accumulation and mineral element uptake in two Rumex japonicus populations from a copper mine and an uncontaminated field sites. Environ Exp Bot 59:59-67

Łabanowska M, Filek M, Kurdziel M, Bednarska E, Dłubacz A, Hartikainen H (2012) Electron paramagnetic resonance (EPR) spectroscopy characterization of wheat grains from plants of different water stress tolerance. J Plant Physiol 169:1234-1242

Lidon FC, Barreiro MG, Ramalho JC (2004) Manganese accumulation in rice: implications for photosynthetic functioning. J Plant Physiol 161:1235-1244
Marschner P (2012) Marschner's mineral nutrition of higher plants. Academic Press, Boston

Millaleo R, Reyes-Diaz M, Alberdi M, Ivanov AG, Krol M, Huner NP (2013) Excess manganese differentially inhibits photosystem I versus II in Arabidopsis thaliana. J Exp Bot 64:343-354

Nickelsen J, Rengstl B (2013) Photosystem II assembly: from cyanobacteria to plants. Annu Rev Plant Biol 64:609-635

Pittman JK (2005) Managing the manganese: molecular mechanisms of manganese transport and homeostasis. New Phytol 167:733-742

Qiu RL, Zhao X, Tang YT, Yu FM, Hu PJ (2008) Antioxidative response to $\mathrm{Cd}$ in a newly discovered cadmium hyperaccumulator Arabis paniculata F. Chemosphere 74:6-12

Santandrea G, Schiff S, Bennici A (1998) Effects of manganese on Nicotiana species cultivated in vitro and characterization of regenerated Mn-tolerant tobacco plants. Plant Sci 132:71-82

Sharma SS, Kaul S, Metwally A, Goyal KC, Finkemeier I, Dietz KJ (2004) Cadmium toxicity to barley (Hordeum vulgare) as affected by varying Fe nutritional status. Plant Sci 166:1287-1295

Sharma P, Jha AB, Dubey RS, Pessarakli M (2012) Reactive oxygen species, oxidative damage, and antioxidative defense mechanism in plants under stressful conditions. J Bot. doi:10.1155/2012/ 217037 (article ID 217037)

Sieprawska A, Filek M, Walas S, Tobiasz A, Mrowiec H, Miszalski Z (2014) Does micro- and macroelement content differentiate grains of sensitive and tolerant wheat varieties? Acta Physiol Plant 36:3095-3100

Sieprawska A, Filek M, Tobiasz A, Walas S, Dudek-Adamska D, Grygo-Szymanko E (2016) Trace elements' uptake and antioxidant response to excess of manganese in in vitro cells of sensitive and tolerant wheat. Acta Physiol Plant 38:1-12

Tanyolac D, Ekmekçi Y, Ünalan S (2007) Changes in photochemical and antioxidant enzyme activities in maize (Zea mays L.) leaves exposed to excess copper. Chemosphere 67:89-98

Tobiasz A, Walas S, Filek M, Mrowiec H, Samsel K, Sieprawska A, Hartikainen H (2014) Evaluation of selenium effect on micro and macroelements distribution to different wheat tissues during principal plant development stages. Biol Plant 58:370-374 